\title{
Determinants of Urban Land Lease Market in an Emerging Economy: Empirical Evidence from Ethiopia
}

\author{
Submitted 10/06/20, $1^{\text {st }}$ revision $14 / 07 / 20,2^{\text {nd }}$ revision $25 / 08 / 20$, accepted $10 / 09 / 20$
}

\author{
H.G. Gebrihet ${ }^{1}$, P. Pillay ${ }^{2}$
}

\begin{abstract}
:
Purpose: The ultimate objective of the study is to examine the determinants of the urban land lease market in an emerging economy with empirical evidence from Ethiopia.

Design/Methodology/Approach: A nomothetic methodology with a standardized and quantitative method of data analysis was adopted for this study. The data was gathered from the Mekelle municipality between 2014-2019. The data was analyzed using the pooled ordinary least square technique. The model produced robust relationships and consistent results with previous studies.

Findings: The study found both supply and demand-driven factors associated with plot markup price. The findings revealed that plot size, payment period, monthly income, plots accessible to basic services, plot location, land use type, and land lease auctioned period associated positively and significantly with the urban land lease markup price. Auctioneers paid a premium for plots having a larger size, extended payment period, access to basic services, and specified for residential housing. On the other hand, distance, and plot inaccessible to basic services associated negatively and significantly with the urban land lease markup price.

Practical Implication: The rapid urbanization in Ethiopia has generated intensified supply and demand-driven challenges for public policy. Hence, the municipality should enhance infrastructure development across all plot locations and exercise strict control of land speculation to increase municipal revenue, and address supply and demand-driven challenges. Moreover, the municipal government should ensure equitable access to urban land by controlling land speculation.

Originality/Value: Several studies that have assessed urban land expansion and administration, however, paid less attention to the urban land lease market. Furthermore, in an economic sense, it is crucial to examine the urban land value determinants from both demand and supply side at a time when less attention has been paid thereto in the literature.
\end{abstract}

Keywords: Land, urban land, land lease market, markup price, Mekelle city, Ethiopia.

JEL codes: E20, E22, E31, E44.

Paper Type: Research Article.

ISSN: 2241-4754, H index 10, Q3.

\footnotetext{
${ }^{1}$ School of Public Leadership, Stellenbosch University, South Africa, ORCID: https://orcid.org/0000-0002-3436-641X,Email: hafte21hg@gmail.com

${ }^{2}$ School of Public Leadership, Stellenbosch University, South Africa, ORCID: https://orcid.org/0000-0002-2101-962X, Email: pregala@spl.sun.ac.za
} 


\section{Introduction}

Because of its different use and physiognomies, land is a key tool for the urban economy (Glumac et al., 2019). Its valuation was introduced to the research community in the second half of the $19^{\text {th }}$ century (Glumac et al., 2019) when the first valuation materialized based on the observation of its features. Over the past 200 years, a gradual but fundamental change in the land market was observed in many countries (Wallace and Williamson, 2006). Since then, the urban land market has become a critical component in determining the density of the urban population, the form, and the price of urban land (Serra et al., 2015).

Understanding the market value, the factors associated with the prices and the supply of urban land is significant for executives to value land, adopt the land tax, and for policymakers to formulate land-related policy reforms (Jaeger, 2013; Gedal and Ellen, 2018). Besides, a functioning urban land market is crucial in enhancing efficient land use by optimizing land provision amid contending uses in the development of effective and efficient spatial patterns and structures of cities (Ding and Zhao, 2014). The success of land markets, however, depends on certainty in democracy, community interest for a land market benefit, and belief in the inviolability of property (Williamson et al., 2010). Urban land markets in many developing countries ${ }^{3}$, however, have suffered from market imperfection, inefficient distribution, pervasive land insecurity, as well as conflicts over urban land (Kolowe, 2014). However, the nature and levels of imperfection differ from one country to another and municipality to another.

Like other developing countries, the current economic progress of Ethiopia demands massive urban land for residential use, industrial expansion, and urban development (Yirga, 2014). As a key policy reform, the government banned private land transactions and declared public ownership thereof (FDRE, 1995; 2011). Urban land markets in the country have been transacting in the form of lease organized by formal institutions, for example, municipalities and City administrations since 1993 (TGE, 1993; FDRE, 2011; Yirga, 2014). This requires qualified human power and better coordination among stakeholders to reduce tedious bureaucracy and unnecessary work steps which result in temptation for acts of corruption and informal payments. However, in many cities ${ }^{4}$ land auction and allotment process took place without considering the growing demand for urban land (Eticha, 2017). This resulted in the illegal construction of houses, informal settlements, and speculation (Yirga, 2014; Eticha, 2017).

\footnotetext{
${ }^{3}$ Ethiopia, Kenya, and Nigeria among the few are struggling to make the land market efficient and speculation free.

${ }^{4}$ Cities such as Bahir dar, Addis Ababa, Hawasssa; towns such as Adigrat, Enticho, Adwa are highly and negatively affected by the illegal construction of houses, informal settlements, and speculation.
} 
Given the significance of land to world-wide development efforts, various studies have intensively assessed urban land expansion, real estate and housing market with less attention towards urban land lease market (Angel et al., 2011; Arribas et al., 2011; Chen and Song, 2014; Hamidi and Ewing, 2014; Vongpraseuth and Choi, 2015; Chen et al., 2016; Zhang and Su, 2016; Xiong and Tan, 2018). Several empirical studies on the land market assessed the determinants of the price of urban land from a supply perspective (Du et al., 2011; Combes et al., 2012; Yang et al., 2015). These studies revealed that the inelasticity of land results in a decrease in its supply, while empirical studies assessed the determinants of the price of urban land from a demand perspective found that socio-economic factors such as income, infrastructure, an increase in population and net migration, environmental concerns, social and neighborhood status affect land market ( Jaeger, 2013; Bayrau and Assefa, 2017). However, in an economic sense, it is crucial to examine the urban land value determinants from both demand and supply side at a time when less attention has been paid thereto in the literature. Therefore, the purpose of this study is to examine the determinants of urban land lease market from both the demand and supply side from empirical evidence gathered at Mekelle City, Ethiopia.

\section{Literature Review}

\subsection{Evolution of Urban Land Markets}

Land is considered as a basic source of production in any country with comprehensive social, economic, political, cultural, and spiritual implications (Williamson et al., 2010). The process of land allocation and affordability thereof, however, depends on the policy and how impartially land is allocated among the people (Owoeye and Adedeji, 2015; Adam, 2019). Unlike other goods and services, land is a factor of production that cannot be produced. Consequently, countries endorse land use and ownership policies that would preserve the economic power, social solidarity, and spiritual attachments of its people. Authors such as Bruce (1998), Van Der Molen (2002), Picarelli (2015) classified land ownership into four groupings. The first category is as a communal/customary ownership to which individual rights are not allocated. The second category is state ownership in which the government controls and manages the land. The third category is individual ownership in which ownership right is given to individuals, while the fourth category is a mixed ownership form where the state and the people own collectively, and the government manages on behalf of the people. These land groupings vary across countries depending on the policies and historical backgrounds to determine the system and type of land market.

The emergence of the urban land lease market has been a major emphasis on land reform in post-1991 in Ethiopia, which shifted urban land market strategy in the country (TGE, 1993). The urban land lease market, which was forbidden during the Derg regime/military government had become a vital system of land allocation and transactions in the urban areas of the country. As part of the decentralization process, 
municipal governments and City administrations have been empowered to manage urban land use which was centralized during the previous governments (Wubneh, 2018).

\subsection{Theoretical Framework}

Nowadays, the population, wealth, scientific innovations, and productive activities are highly concentrated in cities in the global North and South (Macleod and Macleod, 2011; Storper, 2016). This has attracted several scholars such as Malczewski and Ontario (2009), Ja (2020), Murray (2020) amongst others, to develop a theory that fits the context of urban politics. These theories are reviewed in the context of this study as follows.

The location theory is the most appropriate and relevant to this study. Economists assume geographic location as a determinant factor that affects firms, communities, and even nations' economic environment (Kilkenny and Thisse, 1999; Murray, 2020). This theory has also served as a central component of urban economic geography since its emergence, which explains the significance of location (Murray, 2020). The choice of business location depends on the resource endowment, demand for the product, spatial competition, and its distance from the customers (Kilkenny and Thisse, 1999; Murray, 2020). In the context of urban land value, private developers consider the availability of customers, basic infrastructures, economic efficiencies, and service providers to decide won the price of a specific plot. Businesses are always in competition for customers; therefore, they locate a strategic place since the former are on the street. On the other hand, residential locations are selected to maximize household utility in terms of goods, transport costs, and market place (Kilkenny and Thisse, 1999). According to the location theory, plots closer to the urban-industrial areas and customers are more expensive than those a distance from the center. From this theory, it can be inferred that distance of a parcel/plot of land, infrastructural expansions, the number of competitors, and land use type plays a significant role in determining the price of a plot of land.

Central place theory, which was founded by Walter Christaller in 1933, a German scholar from Bavaria to assess the correlation between settlements and their complementary regions is also appropriate for this study. This theory predicts the distribution of services in an economy across geographic locations. It stresses the role of consumers' demand as a key to location choice. To control the potential central places for business use, two economic parameters namely: "the minimum level of demand necessary to support business activity and the maximum distance a consumer is willing to travel to purchase a good" was accentuated (Malczewski and Ontario, 2009). For this theory, the price of land reflects the development condition of the plot, which extended from the Central Business District, Transitional Zone, and to the Sub-Urban Fringe and declined exponentially with rising distance from the center. In this regard, the most luxurious land is located near the center of the 
City and under the Central Business District, while affordable land is located in the remote areas and Sub-Urban Fringes (Kheir and Portnov, 2016).

\subsection{Empirical Review}

Previous studies in the literature have considered possible determinant factors associated with markup prices land across countries. The factors perhaps stem from either supply or demand-driven or both. The supply-driven factors are related to the availability of serviced land amongst others, where the government land-use policies determine the number of plots per lease round (Du et al., 2011; Combes et al., 2012; Yang et al., 2015). Authors like Du et al. (2011) and Yang et al. (2015) revealed that the existing land policies in China empower the municipal government to be the only supplier of land since 2004, which enables them to control land supply and thereby help land developers to acquire land-use rights at a fair competition level in the market.

By contrast, several studies demonstrated that socio-economic factors such as income, infrastructure, an increase in population and net migration, environmental concerns, social and neighborhood status affects the housing market (Kabba and Li, 2011; Ma and Liu, 2013; Kheir and Portnov, 2016; Qu et al., 2020). The findings by Ma and Liu (2013) and Qu et al. (2020) also demonstrate that an improvement in the plot grade and distance to the transportation center impacts on the price of land. Also relevant to this study, scholars Jaeger (2013), Ding and Zhao (2014), Bayrau and Assefa (2017), Wineman and Saweda (2017), Gedal and Ellen (2018), Malaitham et al. (2018) reported that location of the plots, income, development condition of a plot, and distance from the center determines the price of land.

Overall, the previous studies assessed urban land expansion, land market, and the housing market, while less attention was paid to the urban land lease market. However, this study focused on the urban land lease market. Moreover, the previous studies assessed the urban land market either from the supply or demand side at a time, while this study examined the determinants of the urban land lease market from the demand and supply side.

\subsection{Conceptual Framework}

To assess determinant factors associated with markup prices in Mekelle City, a detailed conceptual framework was designed. As illustrated in Figure 1, the land is the collective possession of the people of Ethiopia owned by the state on behalf of the public (FDRE, 1995). The rural area is a terrestrial one that is placed exterior to the municipalities managed by the Regional and Woreda/District government ascendingly, while the Peri-Urban areas are a hinterland near the rural areas where legal and illegal land transactions take place. In urban areas, municipalities allocate land to diverse groups on a lease and allotment bases (FDRE, 2011). This study 
examined the determinants of the urban land lease market from the demand and supply side. Consequently, the following hypotheses were developed.

Figure 1. Conceptual Framework of the Study

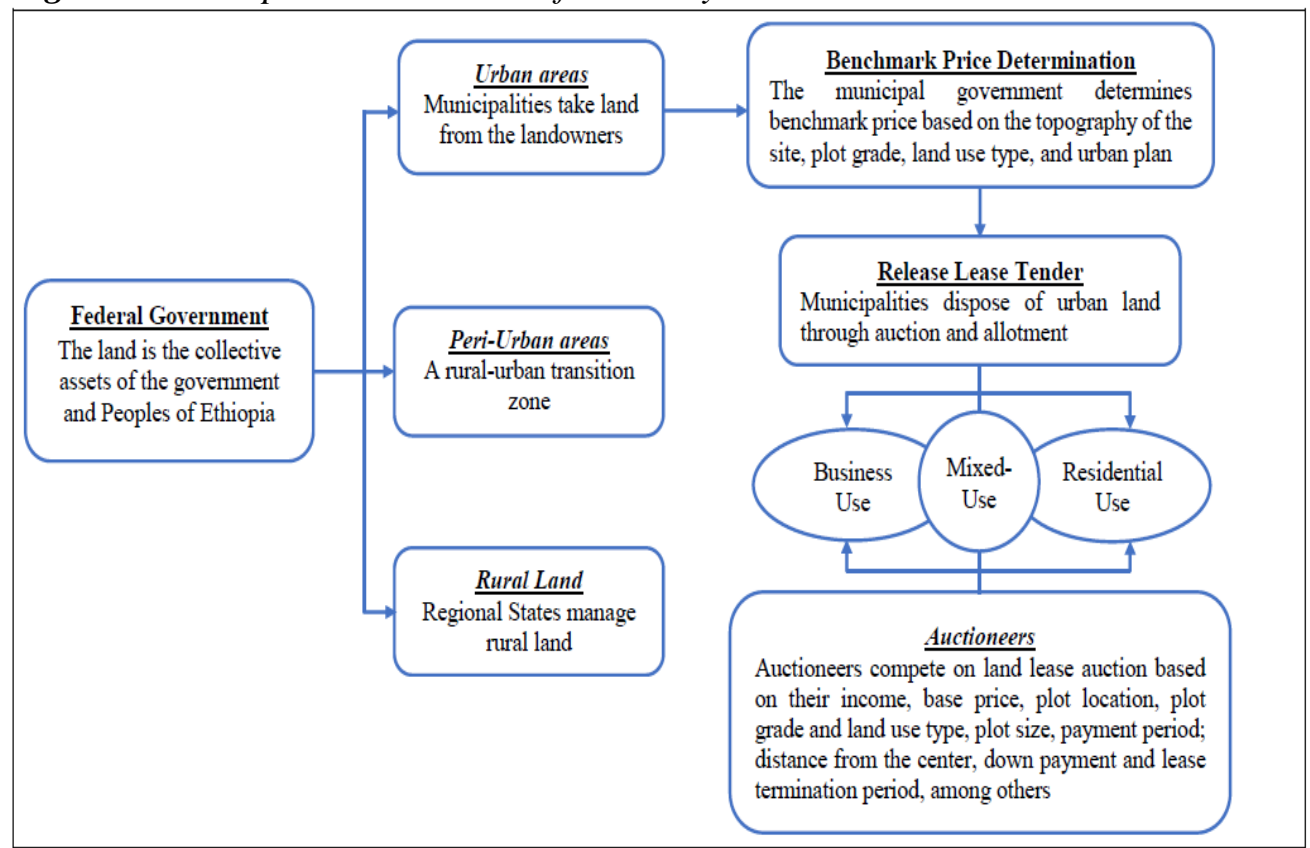

Source: Own Elaboration (2020).

$\boldsymbol{H}_{0:}$ Markup price has no association with plot size; plot payment completion period; auctioneer monthly income; distance in kilometer; base price; down payment; land use type; plot grade; plot location; plot auction period; sex and land auction period. $\boldsymbol{H}_{1}:$ Markup price has an association with plot size; plot payment completion period; auctioneer monthly income; distance in kilometer; base price; down payment; land use type; plot grade; plot location; plot auction period; sex and land auction period.

\section{Research Methodology}

A nomothetic methodology with a standardized and quantitative method of data analysis was adopted for this study. Burrell and Morgan (2019) suggest social science scholars to utilize a nomothetic methodology if their research protocol and technique is to test a hypothesis based on scientific rigor. The hypothesis was verified under systematic precision.

\subsection{Model Specification}

The pooled Ordinary Least Squares (Pooled OLS) regression model was used to examine determinants of markup price in urban land. The model has become an important tool which is utilized by several authors, for example, Pope and Pope 
(2012), Bayrau and Assefa (2017), Wineman and Saweda (2017), Quang and Vu (2019), amongst others to estimate the price of land. Thus, the model can be specified as follows:

$Y t_{i}=\beta_{0}+\beta_{1}(X t)_{i}+t \varepsilon_{i}$

where:

$Y_{i}$ denotes the markup price of the urban land (dependent variable) for the $i^{\text {th }}$ bidder $\beta_{0}$ and $\beta_{1}$ stands for regression intercept and regression coefficient estimates (parameters)

$X_{i}$ signifies the vector of the predictor variables,

$t_{i}$ Denotes the land auction period in years, and $\varepsilon_{i}$ stands for the disturbance term

The OLS regression model, equation [01], for the markup price can be rewritten as follows:

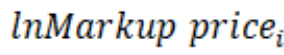

$$
\begin{aligned}
& =\beta_{0}+\beta_{1}(\text { base price })_{i}+\beta_{2}(\text { plot size })_{i}+\beta_{3}(\text { plot location })_{i} \\
& +\beta_{4}(\text { plot grade })_{i}+\beta_{5}(\text { household income })_{i} \\
& +\beta_{6}(\text { payment period })_{i}+\beta_{7}(\text { distance })_{i} \\
& +\beta_{8}(\text { down payment })_{i}+\beta_{9}(\text { lease period })_{i} \\
& +\beta_{10}(\text { land use type })_{i}+\beta_{11}(\text { sex })_{i} \\
& ++\beta_{12}(\text { land auction period })_{i}+\varepsilon_{i}
\end{aligned}
$$

\subsection{Definition and Measurement of Variables}

The markup price was considered as a dependent variable, which was computed by the number of payment bidders offered for a plot measured in Ethiopian Birr ${ }^{5}$ minus the base price of the plot. The markup price per urban plot was transformed into a natural logarithm; the transformed variable (InMarkup price) was utilized as the outcome variable; while various categorical and continuous variables were also employed as explanatory variables as illustrated in Table 1.

Table 1. Description and Definition of Variables included in the Regression Analysis

\begin{tabular}{ll}
\hline Variables & Description \\
\hline Markup price & $\begin{array}{l}\text { Markup price obtained by the amount bidders offered for a plot } \\
\text { minus the base price of the plot, which is measured in Ethiopian Birr }\end{array}$ \\
Plot Size & $\begin{array}{l}\text { Size of the plot is measured in } \mathrm{m}^{2} \\
\text { Payment Period }\end{array}$ \\
$\begin{array}{l}\text { A continuous variable indicating land lease payment completion } \\
\text { period measured in years } \\
\text { The monthly income of the auctioneers measured in Birr }\end{array}$ \\
\hline
\end{tabular}

${ }^{5}$ Birr is the nomenclature for Ethiopian currency. Currently (September/2020), one Birr is USD 36.51 


\begin{tabular}{|c|c|}
\hline Variables & Description \\
\hline \multicolumn{2}{|l|}{ Monthly Income } \\
\hline Distance & The distance of plots to the center of the City measured in Kilometers \\
\hline Base Price & $\begin{array}{l}\text { The base price of the plot per } m^{2} \text { of land measured in Birr, which is } \\
\text { provided by the City administration }\end{array}$ \\
\hline Down Payment & $\begin{array}{l}\text { Down payment measured in Birr, which is an initial payment offered } \\
\text { by bidders with a minimum threshold of } 20 \text { percent of its total price }\end{array}$ \\
\hline Land-use Type & $\begin{array}{l}\text { A dummy variable demonstrating land use type (business }=0 \text {, used as } \\
\text { a reference category } \& \text { residential }=1 \text { ) }\end{array}$ \\
\hline Plot Grade & $\begin{array}{l}\text { A dummy variable indicating a plot grade (poor condition, middle, } \\
\text { and relatively batter development condition) (Transitional zones } \\
\text { (grade- } 2)=0 \text {, used as a reference category, Central Business District } \\
\text { (grade- } 1)=1 \text { and Sub-urban fringes (grade- } 3 \text { ) }=2\end{array}$ \\
\hline Plot Location & $\begin{array}{l}\text { A dummy variable representing a plot location in the sub-cities ( Qiha } \\
=0 \text {, used as a reference category; Adi-Haki=1; Ayder }=2 ; \text { Hawelti }=3 \text {; } \\
\text { Semien }=4 ; \text { Hadnet }=5 \text { ) }\end{array}$ \\
\hline Lease Period & $\begin{array}{l}\text { A dummy variable representing the lease termination period ( } 70 \\
\text { years }=0 \text {, used as a reference category; } 99 \text { years }=1 \text { ) }\end{array}$ \\
\hline Sex & $\begin{array}{l}\text { A binary variable representing the gender of auctioneers (Female }=0 \text {, } \\
\text { used as a reference category; male }=0 \text { ) }\end{array}$ \\
\hline $\begin{array}{l}\text { Plot Auction } \\
\text { Period }\end{array}$ & $\begin{array}{l}\text { A dummy variable representing the plot auction period ( } 2014 \text { years } \\
=0 \text {, used as a reference category; } 2015=1 ; 2016=2 ; 2017=3 ; 2018=5 \text {; } \\
2019=5 \text { ) }\end{array}$ \\
\hline
\end{tabular}

Source: Own Elaboration (2020).

\subsection{Data Source and Sample Selection}

This study considers plots as a unit of analyses and computes a set of urban land lease market for a sample plot auction period. The study examined the determinant factors associated with the markup price of urban land. To address this objective, this study employed secondary data sourced from Mekelle municipality for the plot auction period from 2014 to 2019 . This study utilized a total of 2335 plots, of which the largest 72 percent $(1,671)$ were auctioned to residential urban land lease users, while the remaining 28 percent (664) comprised of business urban land lease users. The lease round period dataset facilitates the establishment and aggregate data of the price of urban land per $\mathrm{m}^{2}$ square for a given plot.

\subsection{Methods of Data Analyses}

Regarding the statistical analysis, descriptive and inferential analysis methods were employed to analyze the data. Thus, all data arithmetic analyses were computed using Stata version 16. It commenced with the descriptive statistics followed by linear regression analysis. Descriptive analysis was employed to assess markup price, base price, plot size, down payment, auctioneer monthly income, payment period, and distance. Besides, descriptive analysis was utilized to compare the markup price across land-use type, plot location, plot grade, sex, and plot auction 
period. Likewise, the trend of demand and supply for urban land lease across plot auction period, trends in plots prepared for auction and actually sold across plot auction period, trends in average markup price, and base price across the plot auction period were examined. Most importantly, linear regression was used to explore the determinants of the markup price.

\section{Results}

The Ethiopian urban land lease proclamation no. 721/2011 empowers regional states and City administrations to allocate urban land for different purposes through auction or allotment (FDRE, 2011). Accordingly, Mekelle City municipality established land development and management processes to auction plots of urban land prepared for various activities (TNRS, 2012). The municipality based on "topography of the site, its economic, social and administrative infrastructure, and urban plan" determines the benchmark price of a specific site of a plot (TNRS, 2012). The office released the plots of urban land for auction at the municipality's base price. The bidders would submit their willingness to pay for a particular plot in a closed envelope. Finally, "the highest bidder shall be declared a winner based on his/her bid price and the amount of down payment he/she offers" (FDRE, 2011; TNRS, 2012).

\subsection{Descriptive Statistics}

The aggregate of the descriptive statistics for the continuous and categorical variables was demonstrated in separate Tables. To compute the markup price, the aggregate of the descriptive statistics for the continuous variables was demonstrated in this study as illustrated in Table 2, while the summary of the descriptive statistics for the categorical variables was conveyed in Table 3 .

Table 2 illustrated the summary statistics of the continuous variables. The mean price of a plot in $m^{2}$ is 13124.79 Birr with a standard deviation of 9187.67 , while the mean base price of a plot in $\mathrm{m}^{2}$ is $637.27 \mathrm{Birr}$ with a standard deviation of 205.64 Birr. In other words, on average, a $1 \mathrm{~m}^{2}$ of plot was found to have a price of 13124.79 Birr, while the average rated base price is 637.27 Birr. The price/ $\mathrm{m}^{2}$ and base price are significant to estimate the markup price of a plot. The markup price is computed by the amount bidders offer for a plot minus the base price. On average, auctioneers are willing to pay $12487.52 \mathrm{Bir} / \mathrm{m}^{2}$ with a standard deviation of 9166.01 Birr. However, the gap between the minimum and maximum is 39050 Birr, which dispersed the distribution. In this case, the median value of the markup price $/ \mathrm{m}^{2}$ of a plot, which is 10614 Birr was considered for discussion.

As described in Table 2, the mean plot size in Mekelle City is $268 \mathrm{~m}^{2}$ with a standard deviation of $150 \mathrm{~m}^{2}$. The median plot size demonstrates $250 \mathrm{~m}^{2}$, which is the physical mid of the plots auctioned. Furthermore, Table 2 illustrates that on 
average, auctioneers who won plots earn 68,902 Birr monthly. Moreover, the average distance of a plot from the center is $3.81 \mathrm{~km}$. Auctioneers travel a minimum of $1 \mathrm{~km}$ and a maximum of $8 \mathrm{~km}$ to arrive at the center. The average down payment of a plot per $m^{2}$ is 20.33 percent (Table 2). In other words, on average, auctioneers initially pay 20.33 percent of the total price of a plot per $\mathrm{m}^{2}$. The average payment completion period of a land lease is 44 years. The payment completion period is included in the auctioneer's lease holding certificate (FDRE, 2011, p. 6232; TNRS, 2012).

Table 2. Descriptive Statistics of Mark-up Price

\begin{tabular}{lllllll}
\hline Variables & Obs & Mean & Std. Dev. & Median & Min & Max \\
\hline Price of a plot $/ m^{2}$ & 2,335 & 13124.79 & 9187.67 & 11221 & 701 & 40121 \\
Base Price of a plot $/ m^{2}$ & 2,335 & 637.27 & 205.64 & 539 & 250 & 1876 \\
Markup Price of a plot $/ m^{2}$ & 2,335 & 12487.52 & 9166.01 & 10614 & 95 & 39145 \\
Plot Size in $m^{2}$ & 2,335 & 268 & 150 & 250 & 108 & 2528 \\
Auctioneers & 2,335 & 68902 & 41,882 & 68900 & 10,000 & 199897 \\
Income & & & & & & \\
Distance in km & 2,335 & 3.81 & 2.01 & 2 & 1 & 8 \\
Down Payment in percent & 2,335 & 20.33 & 0.26 & 20.40 & 20 & 20.6 \\
Payment Period in year & 2,335 & 44 & 9 & 50 & 20 & 50 \\
\hline
\end{tabular}

Source: Own Computation (2020).

Table 3 presented the summary statistics of the proportional differences in land lease distribution across land-use types (business and residential use). Accordingly, out of the total 2,335 plots transferred to auctioneers, approximately 71 percent $(1,671)$ was auctioned for residential use, while the remaining 28 percent (664) was auctioned for business use. This implied that more plots are provided for residential purposes than business utilization. Comparing the markup price across the land use type, the 644 plots categorized under business use were auctioned on average markup price of 13020.38 Birr, while the 1,671 plots categorized under residential use was auctioned on average markup price of 12275.77 Birr (Table 3).

Hence, on average, the markup price of urban plot auctioned for business use is 744.61.24 Birr more than urban land auctioned for residential use. Furthermore, the largest urban land lease 60.64 percent (1416) of the plots was found under plot grade-three (Sub-Urban Fringes) followed by 29.50 percent (689) plots categorized under grade-two (Transitional Zone), while the lowest 9.85 percent (230) plots were categorized under grade-one (Central Business Districts). In other words, most of the plots of land were auctioned without fulfilling the necessary economic, social, and administrative infrastructures because plots under the Sub-Urban Fringes category are considered lower in the standard. On average, the largest markup price of the urban land lease was found under plot grade 1 (Central-Business District) with a mean of 13237.37 Birr. The lowest markup price was found in Sub-Urban Fringes with a mean of 2666 Birr (Table 3). 
Table 3 also described urban land lease locations across the plot auction period. Accordingly, the average plot numbers supplied by Hadnet sub-city were 680 throughout the plot auction period followed by Hawelti and Ayder, which was 608 and 500 respectively. Semien and Qiha contributed a few plots -380 and 87 respectively. The highest markup price of the urban land lease was in Ayder (13132.67 Birr) followed by Adi-Haki (12509.65 Birr) and Semien (12408.38 Birr), while the lowest markup price was in Qiha (11865.99 Birr). Auctioneers were more likely to pay a premium for plots in Ayder and Adi-Haki because both the sub-cities are relatively developed in terms of infrastructures and are close to the center, while Qiha is comparatively less developed and distant to the center than other plot locations.

Of the total 2,335 plots transferred to auctioneers, 82.23 percent $(1,920)$ was won by the male auctioneers while the remaining 17.77 percent (415) was won by female auctioneers. It can be inferred that more plots were bought by male auctioneers (Table 3). Comparing the markup price across gender, the 1920 male auctioneers paid on average a markup price of 12496.92 Birr, while the 415 female auctioneers paid on average a markup price of 12444.02 Birr. Hence, male auctioneers paid 52.9 Birr more than the female auctioneers. Table 3 also illustrated the summary statistics of the proportional differences in the number of plots supplied across the plot auction period (from 2014-2019). Consequently, out of the total 2,335 plots transferred to auctioneers, the highest number of plots were supplied during 2018, 2016, and 2017 with a plot number of 664, 466, and 400 respectively. Comparing the markup price across the plot auction period, the average markup price increased at an accumulative rate across all plot auction periods (Table 3).

Table 3. Summary of the Descriptive Statistics for Categorical Variables

\begin{tabular}{llllllll}
\hline Varia & Group & \multicolumn{6}{l}{ The measure of Center and Dispersion for Markup Price } \\
\cline { 4 - 8 } ble & Variable & N & mean & Std. Dev. Midian & min & max \\
\hline Land & Busines & 664 & 13020.4 & 9130.9 & 11894 & 196 & 38095 \\
Type & s & & & & & & \\
& Resident & 1671 & 12275.8 & 9174.1 & 9959 & 95 & 39145 \\
Plot Grade & ial & & & & & & \\
& CBD & 230 & 13237.4 & 9551 & 12897 & 196 & 39145 \\
& TZ & 689 & 12278.8 & 9095.5 & 10192 & 96 & 39136 \\
& SUR & 1416 & 2666.28 & 9176.1 & 11244 & 95 & 39115 \\
Plot & Qiha & 152 & 11865.9 & 9125 & 8954 & 465 & 37895 \\
Location & Hadnet & 680 & 12318.1 & 9286.1 & 9711 & 196 & 39115 \\
& Semien & 308 & 12408.4 & 8879.8 & 10997 & 324 & 35144 \\
& Hawelti & 608 & 12338.8 & 9149.2 & 9778 & 144 & 37514 \\
& Ayder & 500 & 13132.7 & 9215.1 & 12352 & 95 & 39145 \\
Lease & Adi-Haki & 87 & 12509.7 & 9197.8 & 8950 & 594 & 38994 \\
Period & 70 years & 664 & 13020.4 & 9130.9 & 11894 & 196 & 38095 \\
Sex & 99 years & 1671 & 12275.8 & 9174.1 & 9959 & 95 & 39145 \\
& male & 1920 & 12275.8 & 9174.1 & 9959 & 95 & 39145 \\
& female & 415 & 12444 & 9314.1 & 10508 & 144 & 37895 \\
\hline
\end{tabular}




\begin{tabular}{llllllll}
\hline \multirow{2}{*}{$\begin{array}{l}\text { Varia } \\
\text { ble list }\end{array}$} & $\begin{array}{l}\text { Group } \\
\text { Variable }\end{array}$ & \multicolumn{6}{c}{ The measure of Center and Dispersion for Markup Price } \\
\cline { 3 - 7 } & $\mathbf{N}$ & mean & Std. Dev. Midian & min & max \\
\hline Plot & 2014 & 187 & 2461.4 & 1300.7 & 2361 & 144 & 6907.9 \\
Auction & 2015 & 290 & 3169.98 & 1503.1 & 3145 & 95 & 9394.1 \\
Period & 2016 & 466 & 5091.5 & 1901.7 & 4739 & 576 & 12962 \\
& 2017 & 400 & 11257.1 & 4619.6 & 11227 & 1951 & 36024 \\
& 2018 & 664 & 19526.2 & 6119.7 & 19059 & 4406 & 36147 \\
& 2019 & 328 & 24200.9 & 6090.2 & 24394 & 3754 & 39145 \\
\hline
\end{tabular}

Note: Central Business District $(C B D)=$ Grade 1; Transitional Zone $(T Z)=$ Grade 2; SubUrban Fringe $(S U R)=$ Grade 3

Source: Own Computation (2020).

\subsection{Trends of Supply and Demand for Urban Land Across Plot Auction Period}

Figure 2 illustrates the trends of demand and supply for urban land across the plot auction period. As indicated in Figure 2, the demand for urban land surpasses the land supply. This is true across all plot auction periods specifically the number of competitors highly increased after 2016. On the contrary, land supply has demonstrated a continuous decline except in 2018. In other words, on average from 30 to 38 auctioneers compete for a single plot of land in Mekelle City.

Figure 2. Trends of demand and supply for urban land across plot auction period

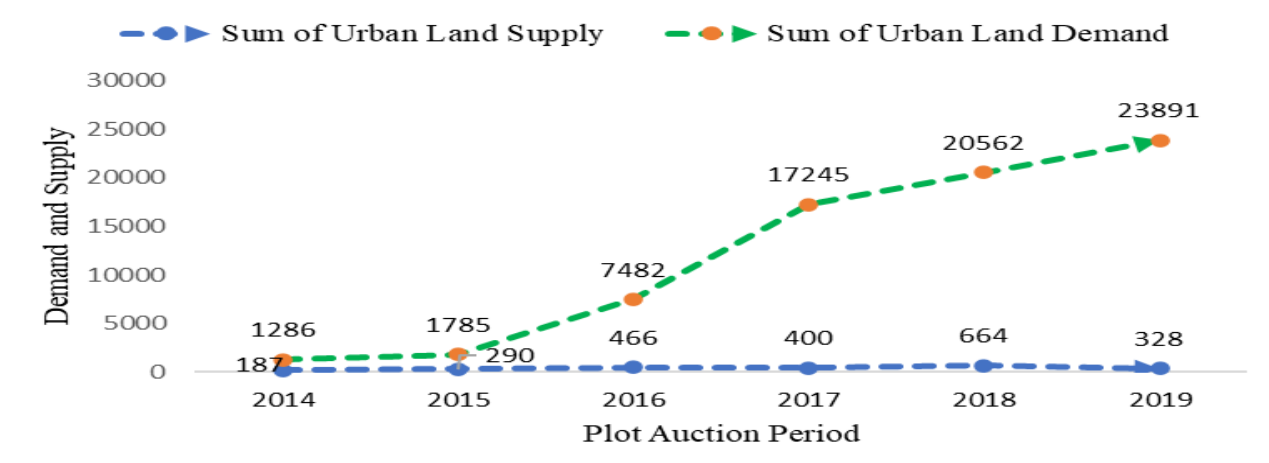

Source: Own Computation (2020).

Figure 3 illustrates the number of urban plots supplied for lease tender and leased at the interval of the sample plot auction period. As indicated in Figure 3, except in 2016 and 2017, not all urban plots supplied by the municipality were sold at the first plot auction period. Although the demand for land outstrips the supply (Figure 2), plots did not auction at its first plot auction period.

Figure 4 illustrates the gap between the average markup price and base price across the urban land auction period. Accordingly, the trend of the average markup price per $\mathrm{m}^{2}$ increased steadily across all plot auction periods while the average plot base price decreased persistently from 2017 to 2019. Moreover, the trend of the plot 
winning price demonstrated an increasing trend, which made the markup price to have an increasing trend. In other words, the municipality's revenue increased from lease round to lease round not because of the base price but the auctioneer's willingness to pay a premium for the plots.

Figure 3. Trends of urban land lease plots across plot auction period

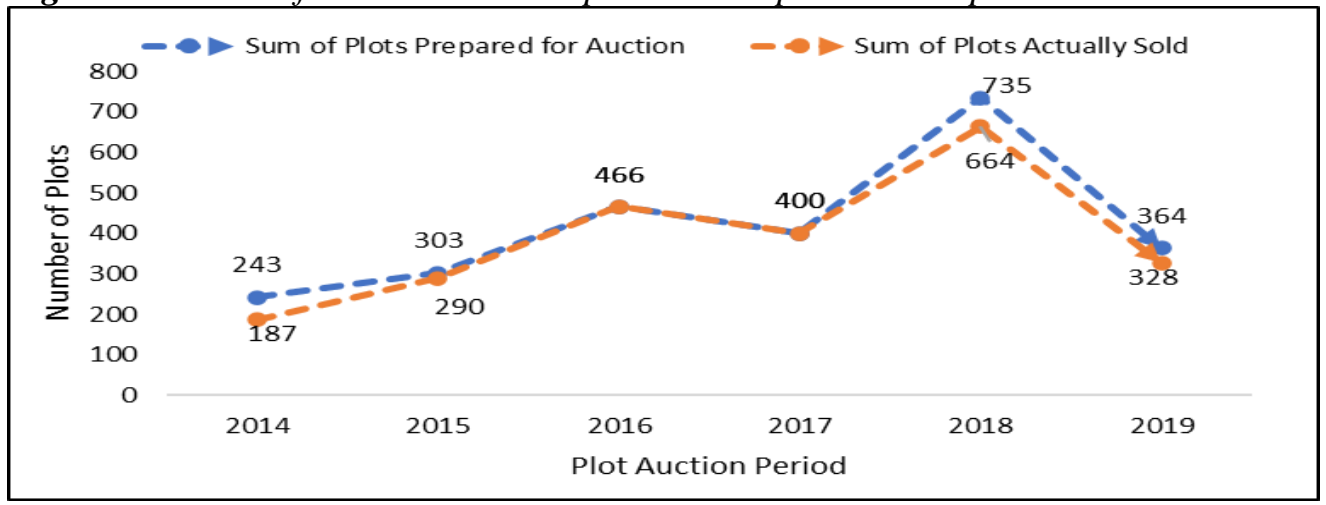

Source: Own Computation (2020).

Figure 4. Average markup and base price across the year

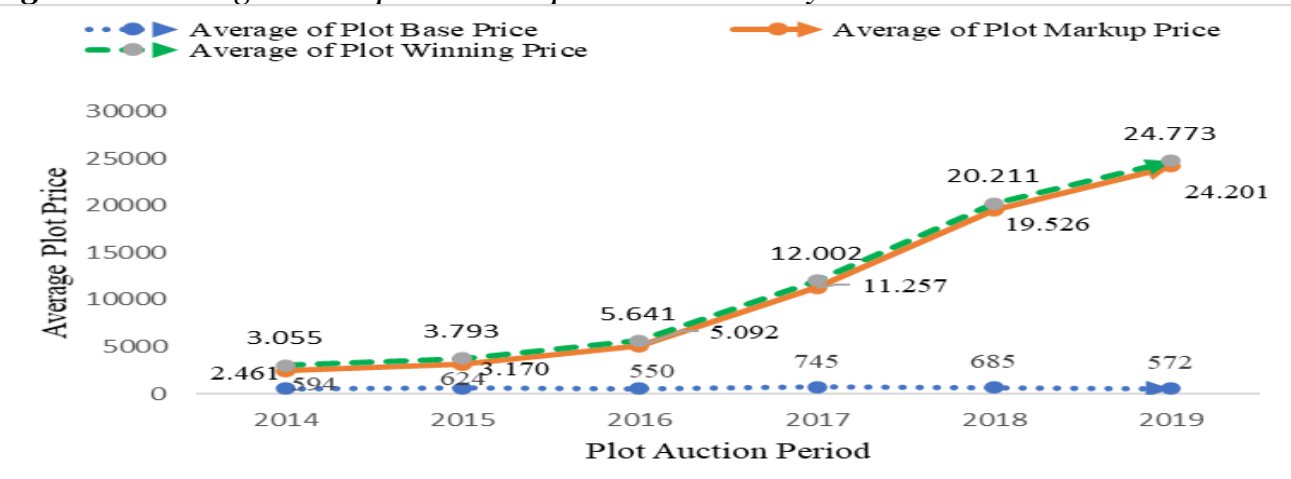

Source: Own Computation (2020).

\subsection{Main Findings}

Table 4 illustrates the estimation outcomes for the determinant factors of the markup price. A positive sign of the estimated regression coefficients reveals a positive relationship between the outcome and predictor variables, while a negative sign indicates the opposite. To mitigate the effect of heteroscedasticity, the markup price per urban plot was transformed into a natural logarithm. Therefore, the transformed variable (InMarkup price) was utilized as the dependent variable. The result of Rsquared demonstrated that the predictor variables explained 60 percent of the variations of the markup price (outcome variable). The findings of the regression analysis revealed that the plot size associated positively with the markup price per plot. A $1 \mathrm{~m}^{2}$ increase in the size of a plot led to a 0.04 percent increase in the average 
markup price of the plot, while holding other determinants of the urban land lease fixed. Similarly, the lease payment period determined positively and significantly the markup price per plot while other factors of the urban land lease remained constant. Accordingly, for each additional year of the lease payment period, the markup price per plot increased by 0.5 percent.

Furthermore, the estimation results revealed that the auctioneers' average monthly income associated positively with the markup price per plot, while other factors remained constant. On average, a 1 percent increase in auctioneers' monthly income increased the markup price per plot by 0.056 percent, while controlling the association of all other determinants of the urban land lease constant. Plot grade 2 (Transitional Zones) was controlled to explore the effect of the two extremes (grade 1 and grade 3). Consequently, compared to the plot grade-2 (Transitional Zones), plots grouped under plot grade-1 (Central Business District) increased the markup price per $m^{2}$ by 5.57 percent while other urban land lease determinants remained constant.

Table 4. Estimated Results of OLS Model

\begin{tabular}{|c|c|c|c|c|c|}
\hline InMarkup price & Coef. & Std. Err. & $\mathbf{P}>|\mathbf{t}|$ & {$[95 \%$ Conf. } & Interval] \\
\hline Plot Size & $.000401^{* * * *}$ & .0001079 & 0.000 & {$[.0001894$} & $.0006126]$ \\
\hline Payment Period & $.0049866^{* * *}$ & .0016364 & 0.002 & {$[.0017777$} & $.0081955]$ \\
\hline $\begin{array}{l}\text { lnAuctioneers } \\
\text { Monthly Income }\end{array}$ & $.0569639^{* * *}$ & .0197928 & 0.004 & {$[.0181504$} & $.0957774]$ \\
\hline Distance & $-.0123602^{* *}$ & .0060517 & 0.041 & {$[-.0242274$} & $-.000493]$ \\
\hline Base Price & -.0002178 & .0002322 & 0.348 & {$[-.0006731$} & $.0002375]$ \\
\hline Down Payment & .0727821 & .0635684 & 0.252 & {$[-.0518749$} & $.1974391]$ \\
\hline \multicolumn{6}{|c|}{ Land Use Type (ref.= Business use) } \\
\hline Residential use & $1.603766^{* * *}$ & .0299426 & 0.000 & {$[1.545049$} & $1.662483]$ \\
\hline \multicolumn{6}{|c|}{ Plot Grade (ref.= Transitional Zone) } \\
\hline Central & $.0571036^{* *}$ & .0282593 & 0.043 & {$[.0016874$} & $.1125198]$ \\
\hline \multicolumn{6}{|l|}{ Business } \\
\hline \multicolumn{6}{|l|}{ District (CBD) } \\
\hline Sub-Urban & $-.0827206^{*}$ & .0470808 & 0.079 & {$[-.1750456$} & $.0096044]$ \\
\hline \multicolumn{6}{|c|}{ Fringe } \\
\hline \multicolumn{6}{|c|}{ Plot Location $($ ref.= Qiha $)$} \\
\hline Ayder & $.1289387^{* *}$ & .0629731 & 0.041 & {$[.0054492$} & $.2524282]$ \\
\hline Hawelti & $.1698289^{* *}$ & .0681965 & 0.013 & {$[.0360963$} & $.3035615]$ \\
\hline Semien & .1036344 & .0638406 & 0.105 & {$[-.0215563$} & $.2288251]$ \\
\hline Hadnet & .1003073 & .0656136 & 0.126 & {$[-.0283604$} & $.2289749]$ \\
\hline Adi-Haki & $.1928742^{* *}$ & .0810342 & 0.017 & {$[.033967$} & $.3517814]$ \\
\hline \multicolumn{6}{|c|}{ Lease Period (ref.= 70 years) } \\
\hline 99 years & .0420305 & .0273285 & 0.124 & {$[-.0115604$} & $.0956215]$ \\
\hline \multicolumn{6}{|l|}{ Sex (ref.= Female) } \\
\hline Male & -.0100304 & .0336682 & 0.766 & {$[-.0760534$} & $.0559925]$ \\
\hline \multicolumn{6}{|c|}{ Plot Auction Period (ref.= 2014) } \\
\hline 2015 & .0763916 & .0496606 & 0.124 & {$[-.0209925$} & $.1737756]$ \\
\hline 2016 & .0513409 & .0492467 & 0.297 & {$[-.0452313$} & $.1479132]$ \\
\hline
\end{tabular}




\begin{tabular}{llcccc}
\hline InMarkup price & Coef. & Std. Err. & $\mathbf{P}>|\mathbf{t}|$ & {$[\mathbf{9 5 \%}$ Conf. } & Interval] \\
\hline \multicolumn{1}{c}{2017} & .0472559 & .0463595 & 0.308 & {$[-.0436547$} & $.1479132]$ \\
2018 & $.102464^{* *}$ & .0449641 & 0.023 & {$[0142898$} & $.1906382]$ \\
2019 & $.0976823^{* *}$ & .0442836 & 0.027 & {$[.0108425$} & $.1845221]$ \\
cons & $5.327703^{* * *}$ & 1.247457 & 0.000 & {$[2.881451$} & $7.773954]$ \\
\hline Number of obs & $=$ & 2,335 & R-squared & $=0.5989$ & \\
F $(21,2313)$ & $=161.07$ & & & \\
Prob $>$ F & $=0.0000$ & \multicolumn{2}{c}{ Root MSE } & $=.59514$ & \\
\hline
\end{tabular}

Note: $i)$ ref. = denotes base reference; ii) $(*),(* *)$, and $(* * *)$ denote significance at 10,5 , and 1 percent levels, respectively

Source: Own Computation (2020).

Most importantly, the land-use types revealed a strong and positive association with the markup price $/ \mathrm{m}^{2}$. Statistically, compared to business land-use, residential land-use increased the markup price per plot by 160.34 percent, while other determinant factors of the urban land lease remained constant. Furthermore, the plot location was among the key determinant factors associated with the urban land lease markup price. Hence, compared to the urban land plots located in the Qiha sub-city, the urban land lease plots located in Ayder, Hawelti, and Adi-Haki sub-cities increased the markup price per plot by $12.89,16.98$, and 19.28 percent, respectively while holding fixed other determinants of the markup price. The coefficient for the plot auction period revealed a positive and significant association with the markup price in the last two years. In other words, compared to urban land lease plots auctioned in 2014, those auctioned in 2018 and 2019 increased the markup price by 10 percent and 9.76 percent, respectively. The same result was reflected in the descriptive statistics (Table 3).

On the contrary, the results of this study revealed that the distance of the plots to the center of the City associated negatively with the markup price of the urban land lease. An increase in one-kilometer distance of the plot from the center decreased the markup price of the urban land lease by 1.2 percent while the other factors remained constant. Auctioneers paid a premium for a plot closer to the center of the City, while less for plots distant from the center. Furthermore, the finding revealed that urban land plot grade-3 associated negatively with the markup price of the urban land lease. Taking plot grade-2 (Transitional Zones) as a benchmark, the Sub-Urban Fringes (plot grade-3) decreased the markup price of the urban land lease by an 8.27 percent, while other aspects remained constant (Table 4). Among the variables included in the regression analysis, base price, down payment, lease period, and sex of the auctioneers do not have a significant association with the markup price.

\section{Discussion}

The present study filled the gap vis-à-vis, the determinants of urban land lease market in Mekelle City, Ethiopia. The descriptive statistics suggest that the markup price offered by auctioneers varies across land-use type, plot location, grade, and 
plot auction period. The number of urban plots demanded was higher than those of the quantity supplied (Figure 2). On the other hand, the number of plots supplied was not sold in the first-round (Figure 3). Statistically speaking, on average 176 (8 percent) of the plots were not sold at the first bid period. This demonstrates that auctioneers are not concluding a contract and taking the land they have won. Questions can be raised: if there is an unmet demand, why plots were not sold at the first bid round. A possible response is land speculation. Urban speculators bid a higher price for the plot of land and won. The speculators knew that the only cash that they would lose if they failed to enter a contract with the municipal office to start construction is the Compulsory Payment Order (CPO). The speculators agreed secretly with the second/third-ranked bidder and offered them more money than the CPO. If the speculators did not agree with either the second or third bidder and if both (former and latter) failed to afford the price, then the plot would be worthless. Because speculators gamble urban land tenders, the municipality is compelled for a second and possibly a third-round tender.

The study revealed both supply and demand-driven factors associated with plot markup price; and a positive and strong association between urban plot size and markup price of the urban land lease, inferring auctioneers paid a premium for larger plots size (Table 4). Thus, estimates of the markup price/willingness to pay of auctioneers could be significantly increased by the plot size.

Another key determinant factor associated with the markup price of the urban land was the lease payment completion period (Table 4). An increase in the payment period resulted in an increased markup price of the leased urban land. This study's finding is consistent with a previous study by Bayrau and Assefa (2017), which indicated that the lease payment completion period associated with the markup price of the urban land lease tender. As indicated in the Tigray national regional state regulation no. 56/2012, auctioneers can pay their lease debt for a plot of up to 50 years (TNRS, 2012). Hence, due to the extended payment period prescribed by the regulation, auctioneers pay a premium price for a plot of urban land, implying that the municipality is making money by extending the lease payment completion period.

Distance from the center of the City to the plot location was one of the major determinant factors that associated negatively with the markup price of the land (Table 4). Thus, the more the auctioneers travel a distance from the center of the City to where the urban plot is located, the lower the markup price of the urban land. The finding of this study is also supported by several previous studies conducted by, inter alia, Ding and Zhao (2014), Jaeger (2013), Malaitham et al. (2018), Gedal and Ellen (2018), which revealed that remoteness of a plot and the auctioneer's willingness to pay for a particular plot had an inverse relationship. Accordingly, when a plot is closer to the center of the City, the number of competitors increases and then the markup price of the plot rises notwithstanding the base price. 
Moreover, the findings of this study demonstrated that the land use type (residential and business urban land uses) associated strongly with the markup price of a plot (Table 4). Hence, the present findings revealed that compared to the business urban land use, residential utilization associated positively with the markup price of a plot. Consistent with the present study, certain empirical studies revealed that the land use type is associated with the markup price of land (Yuan et al., 2019). Another key determinant factor associated with the markup price of the urban land was the urban land plot location. This study revealed that an urban plot location is associated significantly with the markup price of the land. Thus, the finding of the present study is consistent with those of other empirical studies conducted by Yuan et al. (2019, which reported that the location of plots is associated positively with the markup price of a plot.

The urban plot grade was also among the major determinant factors associated with the markup price of the land. The results of this study revealed that an urban plot with relatively better access to physical and administrative infrastructure services had a higher markup price than an urban plot with relatively poor access to basic infrastructure services. In other words, the municipality collects more revenue from plots grouped under the Central Business District (Table 4). This study's findings are also consistent with the criteria set by Mekelle municipality, which assigns a higher benchmark price for plots with relatively better development conditions.

Furthermore, the last two plot auction periods (2018 and 2019) associated positively with the markup price of urban land (Table 4). On average, 45 auctioneers compete per plot in both land-use types in the last two plot auction periods (Figure 3). This number is fourfold higher than the number of auctioneers per plot in Addis Ababa, the capital city of Ethiopia. The study conducted by Bayrau and Assefa (2017) revealed that the average number of bidders per plot in Addis Ababa ranges from 10 to 12 . One of the reasons is that in the last two years the country has been faced with ethnic-based pandemonium. Mekelle City (the main City of Tigray Region, one of the nine regional states of Ethiopia) is relatively peaceful and attracts domestic and foreign investors' interest.

Consequently, the competition for plots for business use escalates ominously. Furthermore, the Tigreans are targeted increasingly because of their ethnic association with the Tigray Peoples Liberation Front (TPLF), which officially separated from the incumbent political party. This led to the displacement of many Tigreans from all aspects of the state and thereby escalated the competition of plots for residential use in Mekelle.

The result of the positive and significant association between auctioneer's monthly income and markup price; the non-significant association between the base price and markup price has significant policy implications. The municipality is earning revenue not because it determined the base price but because of the increasing auctioneer's monthly income. 


\section{Conclusions and Policy Implications}

Ethiopia is undertaking an unprecedented urbanization process in which substantial parcels of rural land have been converted to urban use. This rapid urbanization has generated intensified supply and demand-driven challenges for public policy. From the supply side, relocating land from the rural to urban areas through fair compensation to landowners to providing optimum urban land plots for auction as per the existing demand is an enormous challenge. From the demand side, getting land to be auctioned fairly; preventing land auction from being dominated by several wealthy individuals and land speculators; using urban land as a source of government revenue is a challenging task. Hence, the municipal government should ensure equitable access to urban land by controlling land speculation and harmonizing the supply and demand for urban land.

The price for a particular plot of land was significantly increased by the plot size and extended payment completion period. With a high demand for housing in Mekelle, urban land auctioned for residential use was found to have a strong positive association with the markup price. This is equally true of plot location. Plots located in infrastructurally developed sub-cities had a positive and significant association with the increased price of urban land. The existing ethnic-based conflicts in the country in the last two lease auction years have also contributed towards the escalation of land lease price resulting in an increased markup price. Moreover, the municipality is making more money from the plots grouped under Central Business District and plots near the City because plots grouped under Sub-Urban Fringes and the longer the distance from the center of the City to the location of the plot contributed towards an insignificant amount to the municipal revenue. Therefore, the municipality should enhance the physical and administrative infrastructure to increase its revenue.

Generally, the theories of location and central place are vital for this study in identifying the predictor variables to markup price. Location theory assumes that the price of land reflects the development condition of the plot, which extended from the Central Business District, Transitional Zone, and to the Sub-Urban Fringe and decline its value with increasing distance from the center. Similarly, central place theory considers location, distance to the Central Business District, plot size in $\mathrm{m}^{2}$, financial flows, and infrastructural expansion as determinants of the price of land. On the other hand, the findings of this study supported each theory positively. This study revealed that plots grouped under the Central Business District; a short distance to the center; and categorized under residential land use type play a significant role in determining the price of a piece of land.

\section{Limitations and Future Research Directions}

This study is based on a case study design that examines the determinants of the urban land lease market in an emerging economy with empirical evidence from 
Mekelle City in Ethiopia. The decentralized nature of urban land administration has created room for different regional states to follow their own path of the urban land market based on the federal urban land legislation. Hence, the results of this study may not represent the cities of the other regional states in the country. Therefore, this study encourages future researchers to focus on assessing the variables of the present study to provide a holistic input for policy makers at the country level.

\section{References:}

Adam, A.G. 2019. Thinking Outside the Box and Introducing Land Readjustment Against the Conventional Urban Land Acquisition and Delivery Method in Ethiopia. Land Use Policy, 81, 624-631. https://doi.org/10.1016/j.landusepol.2018.11.028.

Angel, S., Parent, J., Civco, D.L., Blei, A., Potere, D. 2011. The Dimensions of Global Urban Expansion: Estimates and Projections for all Countries, 2000-2050. Progress in Planning, 75(2), 53-107. https://doi.org/10.1016/j.progress.2011.04.001.

Arribas-Bel, D., Nijkamp, P., Scholten, H. 2011. Multidimensional Urban Sprawl in Europe: A Self-organizing Map Approach. Computers, Environment and Urban Systems, 35(4), 263-275. https://doi.org/10.1016/j.compenvurbsys.2010.10.002.

Bayrau, A., Assefa, B. 2017. A Critical Assessment of Urban Land Leasehold System in Ethiopia. Responsible Land Governance Towards an Evidence-Based Approach, 49. Washington D.C., World Bank.

Bruce, J.W. 1998. Country Profiles of Land Tenure: Africa 1996. https://doi.org/10.1017/CBO9781107415324.004.

Burrell, G., Morgan, G. 2019. Sociological Paradigms and Organisational Analysis: Elements of the Sociology of Corporate Life (2nd ed.). London and New York, Routledge Taylor and Fransis Group.

Chen, J., Gao, J., Chen, W. 2016. Urban land expansion and the transitional mechanisms in Nanjing, China. Habitat International, 53, 274-283. https://doi.org/10.1016/j.habitatint.2015.11.040.

Chen, Q., Song, Z. 2014. Accounting for China's Urbanization. China Economic Review, 30, 485-494. https://doi.org/10.1016/j.chieco.2014.07.005.

Combes, P.P., Duranton, G., Gobillon, L. 2012. The Costs of Agglomeration: House and Land Prices in French cities. Review of Economic Studies, 86(4), 1556-1589. https://doi.org/10.1093/restud/rdy063.

Ding, C., Zhao, X. 2014. Land Market, Land Development and Urban Spatial Structure in Beijing. Land Use Policy, 40, 83-90. https://doi.org/10.1016/j.landusepol.2013.10.019.

Du, H., Ma, Y., An, Y. 2011. The Impact of Land Policy on The Relation Between Housing and Land Prices: Evidence from China. Quarterly Review of Economics and Finance, 51(1), 19-27. https://doi.org/10.1016/j.qref.2010.09.004.

Eticha, T. 2017. Land Management Policy and its Implementation in Addis Ababa City Government:-The Case of Arada and Yeka Sub Cities. Addis Ababa University.

FDRE. 1995. The Constitution of the Federal Democratic Republic of Ethiopia Proclamation No. 1/1995. , Pub. L. No. 1, 1.

FDRE. 2011. Urban Lands Lease Holding Proclamation No. 721/2011. Pub. L. No. 4, 6220.

Gedal, M., Ellen, I.G. 2018. Valuing Urban Land: Comparing the Use of Teardown and Vacant Land Sales. Regional Science and Urban Economics, 70(March), 190-203. https://doi.org/10.1016/j.regsciurbeco.2018.03.006.

Glumac, B., Herrera-Gomez, M., Licheron, J. 2019. A Hedonic Urban Land Price Index. 
Land Use Policy, 81(December), 802-812.

https://doi.org/10.1016/j.landusepol.2018.11.032.

Hamidi, S., Ewing, R. 2014. A longitudinal Study of Changes in Urban Sprawl between 2000 and 2010 in the United States. Landscape and Urban Planning, 128, 72-82. https://doi.org/10.1016/j.landurbplan.2014.04.021.

Ja, J. 2020. Land Rent Theory. In International Encyclopedia of Human Geography, 2nd edition, Vol. 8. https://doi.org/10.1016/B978-0-08-102295-5.10666-3.

Jaeger, W.K. 2013. Determinants of Urban Land Market Outcomes: Evidence from California. Land Use Policy, 30(1), 966-973. https://doi.org/10.1016/j.landusepol.2012.02.001.

Kabba, V.T.S., Li, J. 2011. Determinants of Urban Land Price in Freetown, Sierra Leone. Journal of American Science, 7(2), 213-223. Retrieved from http://www.americanscience.org.

Kheir, N., Portnov, B.A. 2016. Economic, Demographic and Environmental Factors Affecting Urban Land Prices in the Arab Sector in Israel. Land Use Policy, 50, 518527. https://doi.org/10.1016/J.LANDUSEPOL.2015.08.031.

Kilkenny, M., Thisse, J.F. 1999. Economics of location: A selective survey. Computers and Operations Research, 26(14), 1369-1394. https://doi.org/10.1016/S03050548(99)00041-6.

Kolowe, P. 2014. The Determinants of Urban Land and Property Values : The Case of Rwanda. University of San Francisco.

Ma, L., Liu, C. 2013. Spatio-Temporal Analysis of House Price Convergence Based on a Demographical Distance. International Journal of Strategic Property Management, 17(3), 263-277. https://doi.org/10.3846/1648715X.2013.822031.

Macleod, G., Macleod, G. 2011. Urban Politics Reconsidered: Growth Machine to Postdemocratic City? https://doi.org/10.1177/0042098011415715.

Malaitham, S., Fukuda, A., Vichiensan, V., Wasuntarasook, V. 2018. Hedonic Pricing Model of Assessed and Market Land Values: A Case Study in Bangkok Metropolitan Area, Thailand. Case Studies on Transport Policy, (September), 0-1. https://doi.org/10.1016/j.cstp.2018.09.008.

Malczewski, J., Ontario, W. 2009. Central Place Theory. In International Encyclopedia of Human Geography, 2nd edition, Vol. 2. https://doi.org/10.1016/B978-0-08-1022955.10332-4.

Murray, A.T. 2020. Location Theory. In International Encyclopedia of Human Geography, second Ed., Vol. 8. https://doi.org/10.1016/B978-0-08-102295-5.10104-0.

Owoeye, O., Adedeji, Y.M. 2015. Urban Land Acquisition for Sustainable Housing Delivery in Akure, Nigeria. International Journal of Developing Societies, 4(1), 10-20. https://doi.org/10.11634/216817831504641.

Picarelli, N. 2015. Assessing Urban Land Tenure Rights in Sub-Saharan Africa.

Pope, D.G., Pope, J.C. 2012. Crime and Property Values: Evidence from the 1990s Crime Drop. Regional Science and Urban Economics, 42(1-2), 177-188. https://doi.org/10.1016/j.regsciurbeco.2011.08.008.

Qu, S., Hu, S., Li, W., Zhang, C., Li, Q., Wang, H. 2020. Temporal Variation in the Effects of Impact Factors on Residential Land Prices. Applied Geography, 114(April), 102124. https://doi.org/10.1016/j.apgeog.2019.102124.

Quang, T., Vu, H.V. 2019. Land Use Policy Land Fragmentation and Household Income: First evidence from Rural Vietnam. Land Use Policy, 89(March), 104247. https://doi.org/10.1016/j.landusepol.2019.104247.

Rodgers, S. 2020. Urban Growth Machine. In International Encyclopedia of Human 
Geography, 2nd Ed., Vol. 14. https://doi.org/10.1016/B978-0-08-102295-5.10348-8. Serra, M.V., Dowall, D.E., Motta, D., Donovan, M. 2015. Urban Land Markets and Urban Land Development: An Examination of Three Brazilian Cities: Brasília, Curitiba and Recife. In IURD Working Paper. Rio de Janeiro, Institute for Applied Economic Research.

Storper, M. 2016. Current Debates in Urban Theory: A critical Assessment, 53(6), 11141136. https://doi.org/10.1177/0042098016634002.

TGE. 1993. Urban Land Lease Holding Proclamation No.80/1993. Pub. L. No. 80, 7.

TNRS. 2012. The Revised Urban land Lease Regulation no. 76/2012. Pub. L. No. 2, 72.

Van Der Molen, P. 2002. Land Administration Theory: Thinking in Terms of Migration of Systems. Land Administration for the New Millennium, 1-18. Washington D.C., FIG XXII International Congress.

Vongpraseuth, T., Choi, C.G. 2015. Globalization, Foreign Direct Investment, and Urban Growth Management: Policies and Conflicts in Vientiane, Laos. Land Use Policy, 42, 790-799. https://doi.org/10.1016/j.landusepol.2014.10.003.

Wallace, J., Williamson, I. 2006. Building land markets. Land Use Policy 23(2):123-135 DOI: $10.1016 / j . l a n d u s e p o l .2004 .07 .003$. https://doi.org/10.1016/j.landusepol.2004.07.003.

Williamson, I., Enemark, S., Wallace, J., Rajabifard, A. 2010. Land Administration for Sustainable Development (1st ed.). https://doi.org/10.2105/AJPH.86.8_Pt_2.P.4.

Wineman, A., Saweda, L. 2017. Land Markets and the Distribution of Land in Northwestern Tanzania. Land Use Policy, 69(October), 550-563. https://doi.org/10.1016/j.landusepol.2017.09.043.

Wubneh, M. 2018. Policies and Praxis of Land Acquisition, Use, and Development in Ethiopia. Land Use Policy, 73(January), 170-183. https://doi.org/10.1016/j.landusepol.2018.01.017.

Xiong, C., Tan, R. 2018. Will the Land Supply Structure Affect the Urban Expansion Form? Habitat International, 75(April), 25-37. https://doi.org/10.1016/j.habitatint.18.04.003.

Yang, Z., Ren, R., Liu, H., Zhang, H. 2015. Land Leasing and Local Government Behaviour in China: Evidence from Beijing. Urban Studies, 52(5), 841-856. https://doi.org/10.1177/0042098014529342.

Yirga, Z. 2014. Critical Analysis of Ethiopian Urban Land Lease Policy Reform since Early 1990s. Engaging the Challenges - Enhancing the Relevance, 1-24. Kuala Lumpur, FIG Congress.

Yuan, F., Dennis, Y., Xiao, W. 2019. Land Use Policy Land Marketization, Fiscal Decentralization, and the Dynamics of Urban Land Prices in Transitional China. Land Use Policy, 89(January), 104208. https://doi.org/10.1016/j.landusepol.2019.104208.

Zhang, Q., Su, S. 2016. Determinants of urban expansion and their relative importance: A comparative analysis of 30 major metropolitans in China. Habitat International, 58, 89-107. https://doi.org/10.1016/j.habitatint.2016.10.003. 